УДК 616.12-005.4-089

\title{
Повна артеріальна реваскуляризація міокарда (досвід одного центру)
}

\author{
Пукас О. Ю., Варбанець С. В., Довгань О. М.
}

ДУ «Науково-практичний медичний центр дитячої кардіології та кардіохірургії МОЗ України» (Київ)

\begin{abstract}
Золотим стандартом хірургічного лікування ішемічної хвороби серця вважається аортокоронарне шунтування (АКШ) з використанням лівої внутрішньогрудної артерії (ЛВГА) та великої підшкірної вени нижніх кінцівок (ВПВ).

Мета роботи - висвітлення власного досвіду застосування повної артеріальної реваскуляризації міокарда у пацієнтів з ізольованими багатосудинними ураженнями коронарних артерій, а також при поєднанні їх із супутньою патологією клапанів серця.

Матеріали та методи. Із січня 2011 року по грудень 2017 року в ДУ «НПМЦДКК МОЗ України» був прооперований 91 пацієнт: усім пацієнтам в якості лікування IXC виконана повна артеріальна реваскуляризація коронарних артерій. У всіх досліджуваних пацієнтів виявлено двосудинні і більше ураження коронарних артерій.

Результати. Виходячи з нашого досвіду, слід зазначити, що операція з використанням двох і більше артеріальних кондуїтів $є$ безпечною, не потребує багато часу і може виконуватись у більшості пацієнтів 3 ішемічною хворобою серця. Згідно з нашими даними, категоричних протипоказань до виконання повної артеріальної реваскуаляризації міокарда немає. Необхідні подальші дослідження з перевірки прохідності шунтів через п'ять, десять і більше років.

Висновки. Деяким пацієнтам із традиційно установленими протипоказаннями до ТАР, такими як виражене ожиріння (IMT>35), хронічні обструктивні захворювання легень, інсулін-залежний цукровий діабет, може бути рекомендований оптимальний вид реваскуляризації міокарда після ретельного обстеження.
\end{abstract}

Ключові слова: тотальна артеріальна реваскуляризація міокарда, внутрішньогрудна артерія, променева артерія, прохідність артеріальних шунтів.

Загальновідомо, що ішемічна хвороба серця посідає перші позиції у структурі смертності не тільки в Україні, а й у світі. Смертність від хвороб систем кровообігу в Україні за 2011 рік складала 459,48 на 100000 населення [1]. На сьогодні золотим стандартом хірургічного лікування ішемічної хвороби серця $\epsilon$ аортокоронарне шунтування (АКШ) з використанням лівої внутрішньогрудної артерії (ЛВГА) та великої підшкірної вени нижніх кінцівок (ВПВ). Розвиваючи ідею В. Колесова щодо нашивання ЛВГА на передню міжшлуночкову гілку лівої коронарної артерії (ПМШГ ЛКА) [2], 30 років тому для реваскуляризації серця при IXC фахівці запропонували використання обох внутрішньогрудних артерій. На той час такий підхід не набув значного поширення [3], поки Tector і колеги не опублікували роботу, присвячену шунтуванню двома внутрішніми грудними артеріями із застосуванням методик Т-анастомозу, секвенційного анастомозу та використанням вільної, тобто відсіченої, правої мамарної артерії в лікуванні пацієнтів з мультисудинним ураженням коронарних артерій [4-6]. Навіть сьогодні у західних країнах відсоток виконання тотальної артеріальної реваскуляризації (ТАР) є досить низьким. Дані Європейської Асоціації серцево-судинних хірургів за 2009 рік вказують, що з усіх аортокоронарних втручань обидві внутрішні грудні артерії використовують лише у 4\% випадків [7]. У 95\% випадків у Сполучених Штатах Америки і більше ніж у 90\% випадків у Великобританії та Австралії при проведенні АКШ нашивається лише один артеріальний шунт [8]. На наше переконання, головною відмінністю ТАР від звичайного АКШ, коли в якості шунтів використовуються ЛВГА і велика підшкірна вена (ПВ) нижніх кінцівок, є те, що артеріальні шунти працюють набагато довше. Тому ми дотримуємося тактики віддавати перевагу повній артеріальній реваскуляризації у пацієнтів відносно молодого віку, в яких відсутні протипоказання для такого методу хірургічного втручання.

Мета роботи - висвітлення власного досвіду застосування повної артеріальної реваскуляризації міокарда у пацієнтів з ізольованими багатосудинними ураженнями коронарних артерій, а також при поєднанні їх із супутньою патологією клапанів серця.

Матеріали та методи. Із січня 2011 року по грудень 2017 року в ДУ «НПМЦДКК МОЗ України» був прооперований 91 пацієнт: в якості лікування IXC всім пацієнтам виконана повна артеріальна реваскуляризація коронарних артерій. У всіх досліджуваних виявлені двосудинні і більше ураження коронарних артерій. 


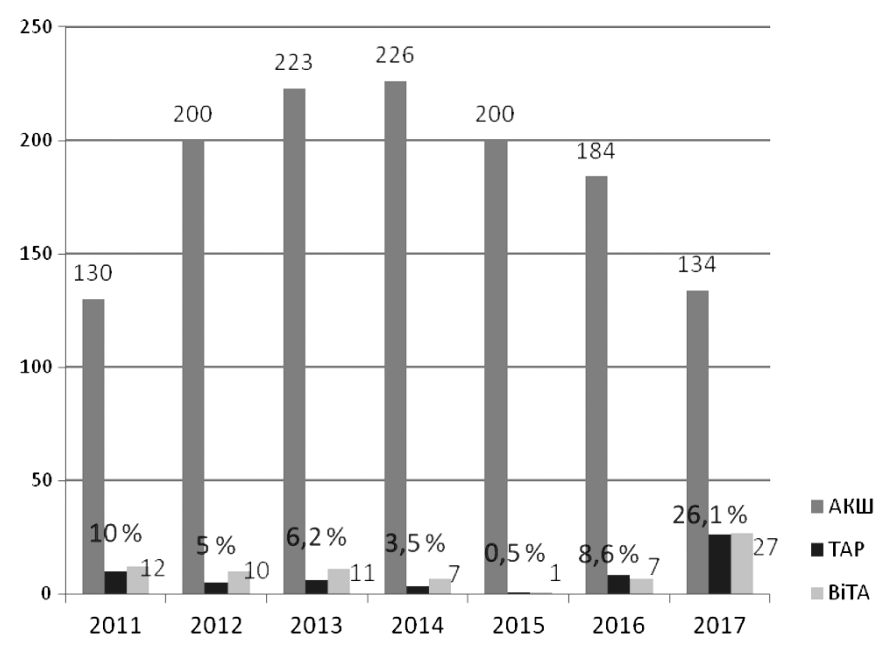

Рис. 1. Співвідношення ТАР міокарда та операцій із використанням обох ВГА зі звичайним АКШ

На діаграмі 1 показана динаміка виконання ТАР порівняно з традиційним АКШ, при якому використовувалися ЛВГА і ПВ нижніх кінцівок, а також вказана кількість хірургічних втручань із використанням двох внутрішньогрудних артерій (ВГА - «ВіТА»).

Із загальної кількості хворих 81 (89\%) пацієнт був чоловічої статі і 10 (11\%) жіночої. Середній вік паці-

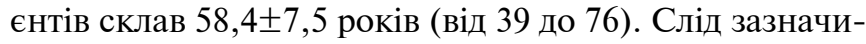
ти, що у 16 (17\%) пацієнтів вік перевищував 65 років. Середній показник індексу маси тіла (IMT) становив $29,05 \pm 3,8$. У 34 (37,3\%) пацієнтів IMT був 30 і вище, що свідчило про надлишок ваги тіла (від 30,0 до 39,1). Доопераційні характеристики пацієнтів наведено в табл. 1.

Задовільна скорочувальна здатність міокарда $(\Phi \mathrm{B}=50-60 \%)$ була у $55(60,5 \%)$ пацієнтів, знижена скорочувальна здатність міокарда (ФВ= нижче $50 \%)-$ у $28(30,7 \%)$ пацієнтів, збережена скорочувальна здатність міокарда (ФВ=60\% і вище) - у $8(8,8 \%)$ пацієнтів. Діагноз цукровий діабет (ЦД) попередньо було встановлено у $22(24,1 \%)$ пацієнтів, з цих 22 пацієнтів у 19

\section{Таблиця 1}

Характеристика пацієнтів до операціі

Доопераційні показники пацієнтів
$\mathrm{N}=91$

Чоловіки

Жінки 81

Вік

IMT

ФВ

ЦД (\%)

NYHA I-II (\%)

NYHA III (\%) використовувались обидві ВГА. За Нью-Йоркською класифікацією серцевої недостатності, в першому і другому класі знаходилось 60 (66\%) пацієнтів, у третьому - 31 (34\%) пацієнт. Планове хірургічне втручання виконували в 86 випадках, в 5 - ургентно. Ізольоване шунтування коронарних артерій виконувалось 82 (90\%) пацієнтам. Шунтування коронарних артерій та/або пластика мітрального клапана проведено 6 пацієнтам; коронарне шунтування (КШ) із пластикою аневризми лівого шлуночка - 1 пацієнту; КШ із протезуванням аортального клапана - 1 пацієнту. В одному випадку виконувалося шунтування коронарних артерій, пластика аневризми лівого шлуночка, пластика мітрального клапана і пластика тристулкового клапана (табл. 2).

Техніка операції. Стандартним доступом, через серединну стернотомію, виділяли ВГА. Екстраплевральним доступом виконували ії скелетизацію. Ми віддаємо перевагу повній скелетизації ВГА, використовуючи при цьому діатермокоагуляцію, кліпування з подальшим відсіченням колатералей. Це дало нам змогу виділяти ВГА достатньої довжини та діаметру, при цьому дистальним орієнтиром була біфуркація артерії, а проксимальним орієнтиром - підключична артерія. Особливістю виділення правої ВГА від лівої було те, що вона більша в діаметрі, тому виділяти ії легше. Після цього ВГА обробляли розчином папаверину, а у випадках, коли артерії відсікали в якості «free graft», додатково вводили розчин ізоптіну інтралюмінально. Променеву артерію завжди виділяли на ніжці (34 пацієнти), оскільки вона більш схильна до спазмування внаслідок лабільності стінки до механічних подразнень. Перед забором променевої артерії обов'язково проводили пробу Алана (час, за який відновлюється кровотік у кисті після повного перетиснення променевої та ліктьової артерій), яка становила менше 6 секунд. Променеву артерію обробляли розчином папаверину зовнішньо та розчином ізоптіну інтралюмінально. У 74 $(81,3 \%)$ хворих нашивання анастомозів виконували із застосуванням штучного кровообігу та помірної гіпотермії $\left(30-32^{\circ} \mathrm{C}\right)$. Для цього виконували канюляцію висхідної аорти та вушка правого передсердя. Для зупинки серцевої діяльності використовували кров'яну

Таблиця 2

Розподіл пацієнтів за типом хірургічного втручання

\begin{tabular}{lc} 
Тип втручання & $\mathbf{N = 9 1}$ \\
\hline Ізольоване КШ & 82 \\
\hline КШ з пластикою або протезуванням МК & 6 \\
\hline КШ з протезуванням АК & 1 \\
\hline КШ з пластикою аневризми ЛШ & 1 \\
\hline КШ, пластика МК, пластика аневризми ЛШ, пла- & 1
\end{tabular}

стика тристулкового клапана 
холодову гіперкаліємічну кардіоплегію. У $62(68,1 \%)$ хворих кардіоплегію прокачували в корінь аорти, а в $6(6,5 \%)$ випадках, де мав місце виражений кальциноз нативних коронарних артерій, - ретроградно в коронарний синус. Комбінацію анте- і ретроградної кардіоплегії проводили $6(6,5 \%)$ пацієнтам. Середня кількість шунтів на одного пацієнта склала 2,79 $\pm 0,88$. Усі дистальні анастомози нашивали ниткою "prolene" 8/0. Басейн лівої коронарної артерії шунтували $65(71,4 \%)$ пацієнтам, басейни обох коронарних артерій шунтували $26(28,6 \%)$ хворим. У першу чергу нашивали анастомоз «кінець у бік» між променевою артерією та задньою міжшлуночковою гілкою (ЗМШГ) правої коронарної артерії (ПКА) (29 випадків), а в 5 випадках виконували секвенційний анастомоз між променевою артерією та ЗМШГ і задньолатеральною гілкою (ЗЛГ) ПКА. У 5 пацієнтів довжини правої ВГА вистачило для того, щоб анастомозувати їі з ЗМШГ ПКА; у таких випадках цей анастомоз нашивали в першу чергу. Потім виконували анастомоз «кінець у бік» між правою ВГА та огинаючою системою ЛКА (69 випадків), а в 15 випадках виконували секвенційний анастомоз правої ВГА і огинаючої системи ЛКА. У 26 випадках спочатку виконували анастомоз між правою ВГА і ЗМШГ ПКА, потім секвенційно із системою огинаючої артерії ЛКА. Анастомоз між лівою ВГА і передньою міжшлуночковою гілкою (ПМШГ) ЛКА нашивали «бік у бік» (90 випадків), в одному випадку ліву ВГА нашивали до огинаючої гілки ЛКА, в 10 випадках лівою ВГА додатково шунтували діагональну артерію, а в 4 випадках - ap-

\section{Таблиця 3}

Варіанти застосованих анастомозів ТАР в оперованих хворих

\begin{tabular}{lcc} 
Шунт & Артерія мішень & $\begin{array}{c}\text { Кількість } \\
\text { (n=254) }\end{array}$ \\
\hline Променева артерія & І & \\
\hline - секвенційно & ЗМШГ ПКА & 29 \\
\hline Права ВГА & Оги ПКА & 5 \\
\hline - секвенційно & Друга гілка огинаючої & 15 \\
\hline “іп situ” & артерії & 69 \\
\hline Ліва ВГА & ЗМГЛКА & 5 \\
\hline - секвенційно & ПМШГЛКА & 90 \\
\hline - секвенційно & Діагональна артерія & 10 \\
\hline Ліва ВГА & Проміжна артерія & 4 \\
\hline
\end{tabular}

\begin{tabular}{lcc}
\hline \multicolumn{2}{c}{ II } \\
\hline Права ВГА & ЗМШГ ПКА & \\
\hline - секвенційно & Огинаюча артерія & 26 \\
\hline Права ВГА & Ліва ВГА & \\
- Т-анастомоз & & 66
\end{tabular}

терію "intermedia” секвенційно. Останнім і дуже важливим етапом операції було формування Т-анастомозу (66 випадків), який виконували «кінець у бік» між правою ВГА і лівою ВГА; при тому ми завжди намагаємося зробити його на такому рівні, щоб він знаходився в порожнині перикарда. В 17 (18,5\%) випадках операція була виконана без використання АШК, у такому разі Т-анастомоз формували в першу чергу (табл. 3.)

Результати та обговорення. Середня тривалість штучного кровообігу (ШК) склала $153 \pm 52$ хв. Середня тривалість перетиснення аорти $-97 \pm 29$ хв. Середня тривалість операції на працюючому серці становила $291 \pm 75$ хв.

В усіх оперованих хворих ранній післяопераційний період протікав без особливих ускладнень. Середня тривалість перебування у відділенні інтенсивної хірургії склала 2,1 $\pm 0,5$ доби, середня тривалість штучної вен-

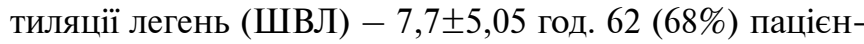
ти потребували інотропної підтримки допаміном - у

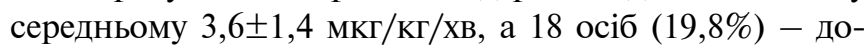
бутаміном, у середньому 2,9 $\pm 0,4$ мкг/кг/хв. Післяопераційний рівень креатиніну становив у середньому $129 \pm 44,5$ ммоль/л. У 36 (39,5\%) хворих через зміни на ЕКГ перевірявся рівень КФК-МВ, який у середньому

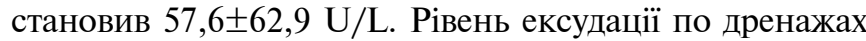
за перші 12 год. становив $302 \pm 117$ мл (від 30 до 1330 мл).

Одному хворому в ранньому післяопераційному періоді проведено рестернотомію у зв'язку із кровотечею. Лише в одному випадку спостерігали інфікування післяопераційної рани в межах підшкірно-жирової клітковини.

Усі оперовані хворі виписані зі стаціонару через 7-12 діб (у середньому через 9 діб). Таким чином, випадків госпітальної летальності серед пацієнтів даної групи не було.

У віддаленому післяопераційному періоді один пацієнт помер від онкологічного захворювання органів дихальної системи через 3 роки і 10 місяців після хірургічного лікування.

Таким чином, виходячи з нашого досвіду, слід зазначити, що операція з використанням двох і більше артеріальних кондуїтів є безпечною, не потребує багато часу і може виконуватись у більшості пацієнтів 3 ішемічною хворобою серця. Згідно з нашими даними, категоричних протипоказань до виконання повної артеріальної реваскуаляризації міокарда немає. Необхідні подальші дослідження з перевірки прохідності шунтів через п'ять, десять і більше років.

На даний час ми не маємо достатньо даних стосовно ефективності повної артеріальної реваскуляризації в оперованих нами хворих у віддалені терміни після операції. Ми сподіваємось на те, що порівняно з традиційним АКШ вони будуть мати перевагу, оскільки вже проведені деякі дослідження, які підтверджують даний факт. Наприклад, робота J. Tatoulis (2015) вка- 
зує на те, що 25\% венозних графтів не функціонують уже через один рік після їх нашивання, а через 10 років - 50\% випадків. Натомість функція артеріальних шунтів зберігається протягом 10 років у $90 \%$ випадків [9]. Виживаність пацієнтів із ТАР на $30 \%$ вища, ніж у пацієнтів зі звичайним АКШ [10]. Дуже важливим є дослідження Dimitrova (2012), в якому виявлено інтралюмінальний синтез вазоактивних речовин - таких, як оксид нітрату, простацикліни та ін. Синтез відбувається з інтактного ендотелію внутрішніх грудних артерій i має протективний вплив на розвиток атеросклерозу дистальної частини нативних коронарних судин [11].

Мультицентрові дослідження вказують на те, що основним показником якості хірургічних втручань із приводу IXC є прохідність шунтів - артеріальних або венозних. Так, прохідність артеріальних шунтів становить близько $90 \%$ після хірургічного втручання, прохідність венозних шунтів становить близько 50\% через десять років після операції [8]. Також зазначається, що реваскуляризація двома артеріальними кондуїтами краща і має кращі результати (навіть якщо другий кондуїт вибору променева артерія) порівняно з проведенням АКШ, при якому використовується один артеріальний графт [14].

На наш погляд, для забезпечення добрих безпосередніх результатів з уникненням ускладнень, а саме інфікування рани, має значення спосіб виділення ВГА. Під час виділення ВГА ми виконували їі скелетизацію, i, як показали результати, в жодного з наших хворих не було серйозних проблем із заживанням рани, незважаючи на те, що серед них були пацієнти з надлишковою вагою і цукровим діабетом. Перевагу даного способу виділення ВГА порівняно з виділенням іiі на ніжці підтверджують дослідження, які проводили Srdjan S. et al. та Nikolaos A. et al. $[12,13]$. Загалом автори стверджують, що інфікування рани в кардіохірургії зустрічається з частотою 2,6-9,6\% [11], розділяючи при цьому глибоку інфекцію рани (Deep sternal wound infection - DSWI) і поверхневу інфекцію рани (superficial wound infection - SWI).

Висновки. Результати нашого дослідження показали, що в більшості пацієнтів можливе проведення тотальної артеріальної реваскуляризації міокарда з мінімальним ризиком летальних випадків і ранніх післяопераційних ускладнень.

Деяким пацієнтам із традиційно установленими протипоказаннями до ТАР (такими, як виражене ожиріння (IMT>35), хронічні обструктивні захворювання легень, інсулін-залежний цукровий діабет) може бути рекомендований оптимальний вид реваскуляризації міокарда після ретельного обстеження.

\section{Література}

1. Гандзюк В. А. Аналіз захворюваності на ішемічну хворобу серця в Україні // Український кардіологічний журнал. - 2014. - № 3. - С. 45-52.

2. Olearchyk A. S., Kolesov V. I. A pioneer of coronary revascularization by internal mammary-coronary artery grafting // Journal of Thoracic and Cardiovascular Surgery. - 1988. - Vol. 96, № 1. - P. 13-18.

3. Barner H. B. Double internal mammary-coronary artery bypass // Arch Surg. - 1974. - Vol. 109. - P. 627-630.

4. T-graft: a new method of coronary arterial revascularization/ Tector A. J., Kress D. C., Schmahl T. M. et al. // Cardiovasc Surg (Torino). - 1994. - Vol. 35. - P. 19-23.

5. Total revascularization with T-grafts / Tector A. J., Amundsen S., Schmahl T. M. et al. // Ann Thorac Surg. 1994. - Vol. 57. - P. 33-38. - discussion 39.

6. Composite arterial conduits for a wider arterial myocardial revascularization / Calafiore A. M., Di Giammarco G., Luciani N. et al. // Ann Thorac Surg. - 1994. - Vol. 90. P. 58-185.

7. Trends in isolated coronary artery bypass grafting: an analysis of the Siciety of Thoracic Surgeons adult cardiac surgery database / ElBardissi A. W., Aranki S. F., Sheng S. et al. // J Thorac Cardiovasc Surg. - 2012. - Vol. 81. P. 143-273.

8. Tatoulis J. Total arterial coronary revascularization - patient selection, stenoses, conduits, targets // Ann Cardiothorac Surg. - 2013. - Vol. 2 (4). - P. 499-506.

9. Total Arterial Revascularization: Achievable and Prognostically Effective - A Multicenter Analysis / Tatoulis J., MD, FRACS, Wynne R., Skillington P. D. // Ann Thorac Surg. - 2015. - Vol. 100. - P. 1268-75.

10. Rosengart T. D., MD, FACS. Total arterial revascularization: When wil its time come? // J Thorac Cardiovasc Surg. 2014. - Vol. 148. - P. 1244-1245.

11. Arterial grafts protect the native coronary vessels from atherosclerotic disease progression / Dimitrova K. R., Hoffman D. M., Geller C. M. et al. // Ann Thorac Surg. 2012. - Vol. 94. - P. 475-481.

12. Effect of Skeletonization of the internal Thoracic Artery for Coronary Revascularization on Incidence of Sternal Wound Infection / Srdjan S., MBBS, BS, James D. et al. // Ann Thorac Surg. - 2010. - Vol. 89. - P. 661-670.

13. Nikolaos A. Papakonstantinou, MD, Nikolaos G. Baikoussis, MD, PhD. Total arterial revascularization: A superior method of cardiac revascularization // Hellenic Journal of Cardiology. - 2016. - Vol. 57. - P. 152-156.

14. Arterial revascularization in primary coronary artery bypass grafting: Direct comparison of 4 strategies - Result of the Stand-in-Y Mammary Study / Guiseppe N., Roberto C., Raffaele Bonifazi et al. // J Thorac Cardiovasc Surg. 2009. - Vol. 137. - P. 1093-1100. 


\title{
Total arterial myocardial revascularization (one center experience)
}

\author{
Pukas O. I., Varbanec S. V., Dovgan O. M. \\ State Institution Scientific-Practical Medical Center of Pediatric Cardiology and Cardiac Surgery Ministry \\ of Health of Ukraine (Kyiv)
}

Today gold standard of surgical treatment of ischemic heart disease is coronary artery bypass surgery (or graft, CABG) with the use of left internal thoracic artery (LITA) and great saphenous vein (GSV) of the lower limb. Objective of the work is to show own experience of performing total arterial myocardial revascularization of patients with isolated multi vascular defeat of coronary artery, in combination with concomitant pathology of the heart valves.

Materials and methods From January 2001 to December 2017 in State Institution «Scientific-Practical Medical Center of Pediatric Cardiology and Cardiac Surgery» Ministry of Health of Ukraine 91 patients were operated, as treatment of ischemic heart disease was performed full arterial vascularization of coronary arteries. All examined patients have two- and more vascular defeat of coronary artery.

Results and discussions. So due to our experience it should be mentioned that two and more arterial conduits CABG is safety, and doesn't take too much time and could be performed in most patients with ischemic heart disease. According to our data there is no strict contraindications of total arterial myocardial revascularization perfoming. But in five, in ten years should graft potency be tested.

Conclusions. Some patients with traditional contraindications to total arterial myocardial revascularization as: overweight (BMI $>35)$, chronic obstructive pulmonary disease, insulin-dependent diabetes mellitus could have (be performed) optimal type of bypass after additional examination.

Key words: full arterial myocardial revascularization, internal thoracic arteries, radial artery, artery graft patency.

\section{Полная артериальная реваскуляризация миокарда (опыт одного центра)}

Пукас А. Ю., Варбанец С. В., Довгань А. М.

ГУ «Научно-практический медицинский центр детской кардиологии и кардиохирургии МОЗ Украины» (Киев)

Золотым стандартом хирургического лечения ишемической болезни сердца считается аортокоронарное шунтирование (АКШ) с использованием левой внутригрудной артерии (ЛВГА) и большой подкожной вены нижних конечностей (БПВ).

Цель работы - освещение собственного опыта использования полной артериальной реваскуляризации миокарда у пациентов с изолированными многососудистыми поражениями коронарных артерий, а также при их сочетании с клапанной патологией сердца.

Материалы и методы. С января 2011 года по декабрь 2017 года в ГУ «НПМЦДКК МОЗ Украины» был прооперирован 91 пациент: в качестве лечения ИБС всем пациентам была выполнена полная артериальная реваскуляризация миокарда. У всех исследуемых пациентов были выявлены двух- и более сосудистые поражения коронарных артерий.

Результаты. Исходя из собственного опыта, следует отметить, что операция с использованием двух и более артериальных кондуитов является безопасной, не требует значительных затрат времени, может использоваться у большинства пациентов с ишемической болезнью сердца. Согласно нашим данным, категорических противопоказаний к выполнению полной артериальной реваскуляризации миокарда нет. Существует необходимость в дальнейших исследованиях для проверки проходимости шунтов через пять, десять и более лет.

Выводы. Некоторым пациентам с традиционно установленными противопоказаниями к ПАР (такими, как выраженное ожирение (ИМТ >35), хронические обструктивные заболевания легких, инсулин-зависимый сахарный диабет) может быть рекомендован оптимальный вид коррекции миокарда после тщательного обследования.

Ключевые слова: тотальная артериальная реваскуляризация миокарда, внутригрудная артерия, лучевая артерия, проходимость артериальных шунтов. 